\title{
Analysis of the determinants of bank liquidity risk: The case of Islamic banks in the UAE.
}

\author{
Khadija Ichrak Addou ${ }^{1 *}$, and Afaf Bensghir ${ }^{1}$ \\ Management and Development of Organizations Laboratory, Higher School of Technology, Mohammed First University, \\ Oujda, Morocco
}

\begin{abstract}
This article aims to examine the principal parameters that impact the liquidity risk incurred by Islamic banks in the UAE. The study examines annual data from four Islamic banks in the UAE. The Data is extracted from their annual activity reports and financial results. A multiple linear regression model is used to assess the impact of six bank-specific variables (Return on Equity, return on assets, size of the bank, liquidity gaps, non-performing loans and capital adequacy ratio) on the liquidity risk of UAE Islamic banks. The designed model shows that ROA and NPL negatively impact the liquidity risk of the studied banks, while the other determinants, namely size, ROE, liquidity gaps and CAR contribute to the improvement of liquidity of UAE banks. Thus, our empirical results complement the existing studies related to the analysis of liquidity risk determinants incurred by Islamic banks operating in the MENA region, especially Emirati banks.
\end{abstract}

\section{INTRODUCTION:}

Liquidity is a concept that is more than ever a topic of financial and banking news. For the Basel Committee on Banking Supervision (BCBS 2008), liquidity represents the ability of an institution to finance the exposure of its assets to meet its obligations at the expected maturity, without incurring unacceptable losses .[1]

Indeed, since the subprime crisis, financial and banking institutions worldwide have been facing liquidity problems. Liquidity risk is, in fact, the primary source of fragility in the global banking and financial system. It is defined by IFSB as the potential loss to Islamic financial services, resulting from their inability either to meet their obligations or to finance increases in assets at maturity, without incurring unacceptable costs or losses. [2]

This subject has received a particular attention by several regulatory authorities and financial institutions at the international level, which have proposed many solutions, including the implementation of additional prudential liquidity ratios (LCR in 2016) and (NSFR in 2019) by the Basel Committee, whose principle is to keep a level of liquidity reserve above the liquidity leakage generated by deposit leaks.

Good liquidity management is one of the significant challenges to the growth and expansion of participatory finance. As a result, the need to deal this critical liquidity risk efficiently and rationally is essential for both conventional and participatory banks, especially since their business is constantly evolving.

Like their counterparts, Islamic banks in turn, are exposed to liquidity risk. Apart from market risk, credit risk and translated commercial risk, the liquidity risk in the case of participating banks is more sensitive. It is due to their short-term contract resources, the particularities of Islamic financial intermediation based on the principles of Islamic law (prohibition of Riba and speculation/sharing of profits and losses, etc.), the absence of an interbank market where Islamic banks can refinance easily, in addition to the weak development of Islamic asset and liability management instruments and their incompatibility with the Shari'a.

These different causes of liquidity risk justify the use of this study, the purpose of which is to raise the following question: What are the determinants of the liquidity risk incurred by Islamic banks and what is their impact on the liquidity position of these banks?

*Corresponding author: k.addou@ump.ac.ma. 
To this end, we propose to conduct an econometric and statistical analysis of the determinants of liquidity risk, in the context of Islamic banks in the United Arab Emirates, for a period of six years from 2014 to 2020.

Our article will be organized as follows: a first part will be devoted to the literature review, a second part to the presentation of the Data and the methodology adopted, a third party to the discussion of the results. In the last piece, we will conclude our study and, we will propose some recommendations for effective management of the liquidity risk and, an optimization of the banking liquidity positions.

\section{LITERATURE REVIEW:}

Liquidity risk management is needed to strengthen the stability of the financial system and, to avoid liquidity shortages that could lead to solvency problems for the bank. Indeed, most financial instruments used for liquidity risk management are based on the Riba principle, which is not in line with Shari'a. As a result, there is a lack of Shari'a-compliant liquid passive asset management (ALM) instruments [3]. Conventional banks are focused on responding effectively to the need for liquidity in the short and medium term. They do this by using different options and interbank market instruments [4]. On the other side, Islamic banks are characterized by minimal access to the money market or interbank because of the obligation to avoid any toxic and interest-bearing instrument [5]. Thus, the situation is all the more penalizing as long as there is no Shari'a- compliant lender of last resort.

In addition, Ray [6] indicates that one of the reasons and source of liquidity problems is the nature of the financing of Islamic banking institutions, which is based on long-term equity contracts. These liquidity problems encountered by Islamic financial institutions are also explained by their primary function, namely the transfer of maturities: the bank receives short-term funds to finance long-term loans [7].

Similarly, they can explain the difficulty of selling financial assets and raising funds reasonably and by the maturity gap between resources and uses in the banks' balance sheets.

Moreover, the subprime crisis has provoked controversies about the pertinent functioning of traditional banks. It has put forward the advantages of Islamic banks as a more resistant alternative to problems, special thanks to the principle of risk-sharing. Subsequently, this has attracted the interest of several researchers interested in comparing the performance of Islamic banks with that of their conventional counterparts. We note that among the various performance criteria, liquidity risk and its proper management dominate the list.

However, the empirical literature on Islamic banks is quite limited, particularly for the MENA region, which covers several countries, including the United Arab Emirates. A minority of empirical studies refer to the estimation of liquidity risk in Islamic banks.

Ahmed [8] conducted a study of the main factors affecting liquidity risk in six Pakistani Islamic banks for a time period of 3 years from 2006 to 2009, using two multivariate statistical regression models. They note that the capital adequacy ratio has a positive and significant correlation with the liquidity risk incurred by these banks, while their size and stability have no significant effect.

Iqbal [9] infers that liquidity risk in Islamic banks is positively and significantly affected by the rate of return on assets, the size of the bank, the CAR ratio, and the rate of return on equity. Anam [10] conducted a comparison of the liquidity risk borne by six conventional banks and four Islamic banks in Bangladesh during the time period from 2006 to 2010 . The result on the one hand in a negative allocation result for Islamic banks between liquidity risk (RL) and net working capital and the rate of return on equity, and on the other hand, in a favourable allocation between the RL and the size of the bank, the CAR and the rate of return on assets. Furthermore, Muharram \& Kurnia[11] show that the liquidity risk of Islamic and traditional banks is negatively impacted by bank capitalisation.

However, a study conducted by Sulaiman [4], which analysed 17 Malaysian Islamic banks, explains that macroeconomic variables such as gross domestic product (GDP), and the rate of inflation impact the liquidity risk. In deficit, the results of [4] $[9,11]$ showed that bank profitability ratios (ROA and ROE) have a positive impact on liquidity risk. 
According to Monki [12] and after an analysis of the methods of measuring and managing different types of risks known by Islamic banks in the MENA region, namely: credit risk, market risk, liquidity risk and operational risk, state that Islamic bankers consider liquidity risk to be the most important, because of the multitude of the constraints as mentioned above, faced by these banks in managing liquidity. For instance, Islamic banks surveyed stated that cash reserves, central bank funding and other Islamic banks are the most widely used liquidity management instruments. In addition, Dietrich stated that bank liquidity is negatively correlated with the size of the banks [13].

Mobin and Ahmad [14], who examined liquidity risk in 15 Malaysian Islamic banks, show that the level of liquidity is characterized by a significant and positive correlation with the profitability and size. Recently, Sobhy [15] compared between liquidity risk management methods in Egyptian conventional and Islamic banks, based on the analysis of the financial states of the two banks during the period (2004-2011). It notes that there is a big difference between liquidity management in the two banking systems, with more efficient and efficient liquidity management at the level of conventional banks.

The existing literature on the determinants of liquidity risk in Islamic banks is quite limited. From this point of view, the main contribution of the document lies in the valorization of the empirical literature related to this subject, in a way even more targeted to specific countries. In addition, it is a study that aims to analyze the determinants of liquidity risk incurred by Islamic UAE banks.

\section{METHODOLOGY, DATA AND HYPOTHESES DEVELOPMENT}

\subsection{Methodology:}

Generally, the empirical work focused on Islamic banks is constantly increasing. Our principal goal is to analyze the determinants that could explain the liquidity risk of four Islamic banks in the United Arab Emirates during the period (2014 to 2020). Thus, the bank-specific variables that will allow us to explain the liquidity risk are as follows:

\subsubsection{Variable to be explained: liquidity risk}

Liquidity risk $(\mathrm{RL})$ is the dependent variable which is measured by the following ratio:

Bank liquidity (equivalent to liquidity risk) $=$ (Liquid assets)/(Total assets)

\subsubsection{Explanatory variables:}

Table 1. List of explanatory variables

\begin{tabular}{|c|c|}
\hline Explanatory variables & Formula \\
\hline CAR (Capital Adequacy Ratio) & CAR it $=\left(\right.$ Capital $_{\text {it }} /$ Total assets it $)$ \\
\hline ROE (Return on equity) & ROE it $=\left(\right.$ net income $\left._{\text {it }}\right) /\left(\right.$ Equity capital $\left._{\text {it }}\right)$ \\
\hline ROA (Return on assets) & ROA it $=\left(\right.$ Net income $\left._{i t}\right) /\left(\right.$ Total assets $\left.{ }_{i t}\right)$ \\
\hline NPL (Non-performing loans) & NPL it $=$ non-performing loans it /gross loans it \\
\hline Size of the bank & Size it $=$ logarithm of the total assets it \\
\hline Liquidity gap & Liquidity gaps it $=\ln \left[(\right.$ total assets it $)-\left(\right.$ total liabilities $\left.\left.{ }_{i t}\right)\right]$ \\
\hline
\end{tabular}

Source: Constructed by the authors. 


\subsection{Model:}

This study focuses on investigating the main determinants of liquidity risk in four banks among the Islamic UAE banks by gauging the impact of six bank-specific variables: CAR, ROA, ROE, size, liquidity gaps, and the NPL.

For this objective, we use the multiple linear regression method since the variable to be explained, namely the RL, is a quantitative variable, which will be described according to several explanatory variables. We will also suppose that the relationship between these two types of variables is linear.

Thus, our proposed model seems coherent with the general literature on the determinants of bank liquidity risk and, it is presented as follows:

$$
\text { Liquidity risk }=f(C A R ; N P L ; R O A ; R O E ; \text { size; liquidity gaps })
$$

This study states that bank liquidity is a function of the ratio of capital adequacy (CAR), non-performing loans (NPL), Return on assets (ROA), Return on equity (ROE), bank size, and liquidity gaps.

We write equation as follows:

$$
R L_{t}=\beta_{0}+\beta_{1} \text { size }_{i t}+\beta_{2} R O A_{i t}+\beta_{3} R O E_{i t}+\beta_{4} N P L_{i t}+\beta_{5} C A R_{i t}+\beta_{6} \text { liquidity gaps }_{i t}+\varepsilon_{i t} .
$$

Where:

-i represents the bank;

$-t$ means time (our time period is from 2014 to 2020);

- LR represents liquidity risk (the equivalent of bank liquidity);

$-\beta_{0}$ is the parameter to be estimated ;

$-\varepsilon_{\mathrm{it}}$ is the error term.

\subsection{Data:}

To achieve our objective, we relied mainly on the annual activity reports, results and financial statements of 4 Islamic Emirati banks during the time period from 2014 to 2020. These banks are:

1) Abu Dhabi Islamic Bank

2) Dubai Islamic Bank PJSC

3) Noor Bank

4) Al Hilal Bank PJSC

\subsection{Hypotheses:}

Based on the literature and the description of the variables, we can formulate the following hypotheses that will either be confirmed or refuted.

H1: Bank capitalization positively impacts bank liquidity.

H2: The bank size positively impacts its liquidity.

H3: An increase in ROA, ROE profitability ratios positively impacts bank liquidity.

H4: The NPL hurts bank liquidity.

H5: Liquidity gaps harms bank liquidity. 


\section{EMPIRICAL RESULTS:}

\subsection{Descriptive statistics:}

Figure1 presents descriptive statistics on liquidity risk and each factor, including the size of the bank, ROA, ROE, CAR, NPL and liquidity gaps for the four Islamic Emirati banks studied.

The descriptive statistics results, especially the mean value, the standard deviation (Std), the maximum and the minimum of these different variables, are presented as follows:

Table 2. Descriptive statistics results.

\begin{tabular}{|c|c|c|c|c|c|c|c|}
\cline { 2 - 8 } \multicolumn{1}{c|}{} & RL & $\begin{array}{c}\text { Liquidity } \\
\text { Gaps }\end{array}$ & CAR & SIZE & ROA & ROE & NPL \\
\hline count & 24.000000 & 24.000000 & 24.000000 & 24.000000 & 24.000000 & 24.000000 & 24.000000 \\
\hline mean & 0.112242 & 9.550895 & 0.167642 & 4.805000 & 0.017300 & 0.173162 & 0.034268 \\
\hline std & 0.033136 & 2.910666 & 0.016028 & 1.047557 & 0.005754 & 0.042686 & 0.010638 \\
\hline min & 0.065000 & 5.420000 & 0.128700 & 3.270000 & 0.009000 & 0.096000 & 0.001100 \\
\hline $25 \%$ & 0.083050 & 7.070000 & 0.158900 & 4.037000 & 0.012600 & 0.143450 & 0.034000 \\
\hline $50 \%$ & 0.0109700 & 10.030000 & 0.172000 & 5.106000 & 0.017700 & 0.178000 & 0.034000 \\
\hline $75 \%$ & 0.127500 & 10.560000 & 0.179000 & 5.354500 & 0.021850 & 0.199449 & 0.034000 \\
\hline $\max$ & 0.188000 & 15.670000 & 0.194000 & 7.670000 & 0.028000 & 0.279769 & 0.057000 \\
\hline
\end{tabular}

Source: Results extracted from PYTHON

The profitability performance of the banks studied is analyzed using two profitability measures ROA and ROE. Thus, the coefficient of return on assets, also called the (ROA), is obtained by the ratio of profits on assets. It is an essential yardstick of a bank's profitability since it enables it to assess its ability to manage the resources at its disposal well compared to previous periods. On average, the ROA ratio is equal to $1,73 \%$.

In addition, the profitability ratio or return on equity (ROE), also known as financial profitability, translates the annual return on equity compared to the profits made. This ratio allows us to measure the profitability of a bank, and the profitability of the capital invested by the shareholders, since it highlights the profitability of their investment. The results show a definite situation in all profitability measures of the UAE Islamic banks studied. On average, the ROE ratio is equal to $1.73 \%$.

The Emirati Islamic banks in our study have the highest variance. In our case, the highest standard deviation is for liquidity variance (2.91), followed by size (1.047), ROE (0.042), CAR (0.016), NPL (0.010), ROA (0.0057). It is additionally noted that in the case of these four Emirati Islamic banks, the average liquidity gap (9.55) is the highest compared to the other variables, followed by the average size (4.80).

\subsection{Regression results:}

The results presented are derived from the implementation of theoretical choices made throughout the different phases of our research. Thus, their validity comes from the consistency of the general concept of the research defined, to answer the problem of the determinants of liquidity risk in Islamic banks in the UAE. For this purpose, the use of a data processing device was necessary. 
Table 3. Determinants of liquidity risk in Islamic banks

\begin{tabular}{|c|c|c|c|c|c|c|}
\cline { 2 - 7 } \multicolumn{1}{c|}{} & Coef & std err & $\mathrm{t}$ & $\mathrm{P}>|\mathrm{t}|$ & {$[0,025$} & $0,975]$ \\
\hline Ecarts & 0,0013 & 0,004 & 0,301 & 0,768 & $-0,008$ & 0,011 \\
\hline CAR & 0,3722 & 0,301 & 1,237 & 0,238 & $-0,278$ & 1,022 \\
\hline SIZE & 0,0015 & 0,013 & 0,12 & 0,906 & $-0,026$ & 0,029 \\
\hline ROA & $-1,1483$ & 1,337 & $-0,859$ & 0,406 & $-4,038$ & 1,741 \\
\hline ROE & 0,3526 & 0,174 & 2,031 & 0,063 & $-0,022$ & 0,728 \\
\hline NPL & $-0,3362$ & 0,787 & $-0,427$ & 0,676 & $-2,037$ & 1,365 \\
\hline
\end{tabular}

Source: Results extracted from PYTHON.

$$
\begin{gathered}
\text { LR it }=0+0.0013 \text { Liquidity gaps }+0.3722 \mathrm{CAR}+0.0015 \text { Size }-1.1483 \mathrm{ROA}+0.3526 \mathrm{ROE}- \\
0.3362 \mathrm{NPL}+\text { Eit. }
\end{gathered}
$$

According to the results above, ROA impacts negatively and significantly the value of bank liquidity risk, followed by NPL, which also has a negative and relatively significant impact on the value of the bank liquidity of the UAE Islamic banks studied. On the other hand, CAR and ROE positively impact the liquidity of Islamic banks with coefficients of 0.3722 and 0.3526 , respectively. Moreover, the contribution of the size of the bank and the liquidity gaps is not very large.

Capital adequacy has a positive and significant relationship with the liquidity of Islamic banks. This result implies that better capitalized Islamic banks are more immune to liquidity risk. Moreover, they can even use their capital to cover their maturity dates and thus suffer fewer difficulties in their liquidity position. However, the capital adequacy ratio (CAR) coefficient is statistically significant, confirming our first hypothesis indicating a positive relation between liquidity and bank capitalization.

Moreover, the positive relationship between size and liquidity risk suggests that size is one element that contributes to the stability of banks. As a result, banks will be able to gain a significant market share and generate higher profits. This result confirms our second hypothesis. Thus, our result is similar to those of $[9,10]$.

As for the bank profitability measured by the ratios (ROA and ROE), it does not seem to have a significant explanation of the evolution of bank liquidity. Subsequently, we cannot deny or confirm our third hypothesis.

Between NPLs and liquidity risk, there is a close and negative relationship that could eventually lead to an illiquidity situation. Furthermore, the Islamic banking system is based on fundamental principles, particularly profit and loss sharing (PLS) and participatory financing methods such as Mudharaba and Musharaka. Of course, the latter are backed by real projects that are legal and not prohibited by the Shari'a and involve investors and entrepreneurs and share profits in a cooperative liquidity risk management program [7].

However, by using these financing methods, Islamic banks are faced with a problem of information asymmetry and have less power over the decisions taken by the financed company [16].

Similarly, a borrower at risk could constitute an outstanding debt for the bank, since it must absorb losses either totally (case of Mudharaba) or partially (case of Musharaka). Indeed, Islamic banking institutions are not allowed to use liquidity management instruments of conventional banks since they are based on the sale of debt and speculative methods, in addition to options and swaps deemed not compliant with the Shari'a. In short, the NPL becomes negatively linked to the liquidity of Islamic banks $[17,18]$. Thus, our fourth hypothesis is confirmed. 
Based on our results, we find that the liquidity gaps are positively related to the liquidity of Islamic banks. We note therefore that liquidity gaps play a crucial role in providing liquidity to banks. Generally, liquidity gaps are widening through the dominance of real asset-based financing. Our result refutes our fifth hypothesis is predicting a positive influence of this variable on the liquidity of Islamic banks. It is also compatible with the results found by the study of Muharram \& Kurnia [11].

Concerning $\mathrm{P}>|\mathrm{t}|$, it is one of the most important statistics. Its principle consists of using the $\mathrm{t}$-statistic to produce the p-value, a measure of the probability that the coefficients are measured by chance via our model. In our case, the p-value of 0.063 for the variable ROE indicates that there is a $6.3 \%$ chance that this variable does not affect the dependent variable, which is the liquidity risk. On the other hand, the p-value of 0.906 for the Size variable indicates that there is a $90.6 \%$ chance that this variable does not affect the liquidity risk.

\section{DISCUSSION:}

In order to evaluate the quality of the model's fit and to validate it, we used the analysis of some results obtained:

Table 4. Overview of the characteristics of the model.

\begin{tabular}{|l|l|}
\hline R-squared & 0.943 \\
\hline Adj. R-squared & 0.917 \\
\hline F-statistic & 35.80 \\
\hline Prob (F-statistic) & $2.38 \mathrm{e}-07$ \\
\hline
\end{tabular}

Source: Results extracted from PYTHON

The R-squared, also called the coefficient of determination represents the measure of the part of the dependent variable explained by the mutations of our independent variables. In percentage terms, 0.943 would indicate that our model explains $94.3 \%$ of the change in our dependent variable, "liquidity risk".

The adjusted R-squared, or the adjusted coefficient of determination of the model, is a corrected version of the $\mathrm{R}$-squared that is changed by the number of variables in a regression model. In our case, the adjusted R-squared is very high (0.917). This indicates that the additional input variables add value to our model.

Concerning the Probability (F-Statistic), it shows the overall importance of the regression. In other words, it assesses the level of significance of all the variables. The null hypothesis for this metric is "all regression coefficients are equal to zero". Probability (F statistics) is the probability that the null hypothesis is true. Based on the above results, the chance $(2.38 \mathrm{e}-07)$ is close to zero. This result indicate that the regression of our model is significant.

\section{${ }^{\star}$ Durbin-Watson Test:}

Durbin-Watson is a measure of homoscedasticity, which describes a uniform distribution of errors in our database. The perfect homoscedasticity is between 1 and 2. In our case, the Durbin-Watson result is $\boldsymbol{d}=\mathbf{1 , 8 7 6}$, implying that the regression results are reliable on the interpretation side of this metric and that the residues are correlated.

\section{CONCLUSION:}

The risks at the level of Islamic banks are entangled, and it is difficult to separate the different risk classes: credit risk, operational risk, solvency risk, Shari'a compliance risk, or liquidity risk. The latter's importance, the specificities of Islamic banks and the challenges facing banks have motivated us to dedicate this paper to the determinants of liquidity risk for this type of bank, in this case, the UAE Islamic banks.

Our main contribution lies in determining the factors that impact the liquidity risk movement. For example, the study was evaluated using the multiple linear regression method and the econometric model created for the Islamic banks studied proved to be significant. The results of our analysis showed that certain variables such as CAR and ROE have a positive and significant impact on bank liquidity, more than size and liquidity gaps. However, the ROA and the NPL harm bank liquidity and therefore contribute to the increase in liquidity risk incurred by these banks. 
In this respect, effective liquidity risk management is necessary not only to guarantee the stability of participating banks, but also to maintain the stability and strengthen the overall financial and banking system, and especially to avoid the banking failures and liquidity crises that have already occurred.

Following the regulatory reforms, it is expected that the two banking systems will be placed on an equal footing in terms of capital and liquidity. Thus, to optimize the liquidity position of participating banks, particularly in the dual banking system, it is recommended to take their specific features into account when establishing regulatory and supervisory arrangements. Similarly, the establishment of an appropriate monetary circuit for the refinancing of Islamic banks and the development of a well-organized Islamic interbank market become a necessity to provide Islamic banks with well-designed interbank instruments for dynamic banking transactions. This must also be associated with strengthening the capacity of Islamic banks in terms of collecting demand resources and investment deposits. It is even suggested to opt for Sukuks in the short time as they contribute to the development of the Islamic money market [19].

Furthermore, it is recommended to adopt Takaful funds as a new liquidity management product that would be one of the best solutions to the liquidity problems encountered by participating banks [20].

Our work could be extended by using a larger sample of Islamic banks operating in several countries in different continents, benchmarking with their conventional counterparts and focusing more on the prudential liquidity ratios (NSFR and LCR) required by the Basel Committee (Basel III), which are pretty complicated to apply and implement, especially in the case of Islamic banks, given their specific features in terms of balance sheet structure and liquidity management.

*This research work is financially supported by the National Center for Scientific and Technical Research (CNRST) of Morocco. The authors of this article would like to express their sincere thanks to the director of CNRST and his staff.

\section{References:}

1. BCBS, Liquidity Risk: Management and Supervisory Challenges, Bank for International Settlements, February (2008).

2. Islamic Financial Services Board, Guiding principles of risk Management for Institutions (Other than Insurance Institutions) Offering Only Islamic Financial Services, (2005).

3. MF. Akhtar, A.Khizer, S.Sadaqat, Liquidity risk management: A comparative study between conventional and Islamic banks of Pakistan, Journal of Research in Business, 1, 35-44 (2011).

4. AA. Sulaiman, TM. Mohammad, ML. Samsudin, How Islamic banks of Malaysia managing liquidity? An emphasis on confronting economic cycles, International Journal of Business and Social Science, 4, N7, (2013).

5. M. ACHIBANE \& I. FENNASSI ADDOULI, Liquidity risk management by the development of the Moroccan money market (case of Islamic banks), Review of Control, Accounting and Auditing (CCA), 4, Nº1, (2020).

6. ND. Ray, Arab Islamic Banking and the Renewal of Islamic Law, Graham and Troutman Limited, London, (1995).

7. A. Khomsi, F. Britel, Liquidity Risk Management: A Comparison of Islamic and Conventional Banks, International Journal of Business \& Economic Strategy (IJBES), 9, 71-76 (2018).

8. N. Ahmed, MF. Akhtar, M. Usman, Risk Management Practices and Islamic Banks: An Empirical Investigation from Pakistan, Interdisciplinary Journal of Research in Business, 1, $\mathrm{N}^{\circ} 6,50-57$ (2011).

9. S. Anam, S. Bin Hasan, HAE. Huda, A. Uddin, MM. Hossain, Liquidity Risk Management: A comparative study between Conventional and Islamic banks of Bangladesh, Research Journal of Economics, Business and ICT, 5, (2012).

10. A. Iqbal, Liquidity risk management: A Comparative Study between Conventional and Islamic Banks of Pakistan, 
Global Journal of Management and Business Research, 12, ํ55 (2012).

11. H. Muharam, HP. Kurnia, The influence of fundamental factors to liquidity risk on the banking industry: comparative study between Islamic and conventional banks in Indonesia, Conference in Business. Accounting and Management (Cbam), (Unissula, Semarang Indonesia), 1, 359-368 (2012).

12. RB. Monki, A. Echchabi, D. Azouzi, and H. Rachdi, Risk management tools practiced in Islamic banks: evidence in MENA region, Journal of Islamic Accounting and Business Research, 5 N 1, 77-97 (2014).

13. A. Dietrich, K. Hess, G. Wanzenried, The good and bad news about the new liquidity rules of Basel III in Western European countries, Journal of Banking and Finance, 44, 13-25 (2014).

14. MA. Mobin, A. Abu Umar Faruq, Liquidity risk management in Islamic banks: a panel approach to the Malaysian market, Sydney International Business Research Conference, University of Western Sydney, Sydney, Australia, (2015).

15. NA. Sobhy, Liquidity risk management: conventional versus Islamic banks in Egypt, Journal of Islamic Accounting and Business Research, $8 \mathrm{~N}^{\circ} 1,100-128$ (2017).

16. A. Ghenimi, and MAB. Omri, Determinants of liquidity risk in Islamic banks: the case of the MENA region, the management and organization review, 127-136 (2018).

17. M. Iqbal, DT. Llewellyn, Islamic Banking and Finance: New Perspectives on Profit Sharing and Risk, Cheltenham: Edward Elgar, 1-14 (2002).

18. V. Sundararajan, L. Errico, Islamic Financial Institutions and Products in the Global Financial System: Key Issues in Risk Management and Challenges Ahead, IMF Working Paper WP 02/192, (2002).

19. Islamic Financial Services Board (IFSB), Technical note on issues in strengthening liquidity management of institutions offering Islamic financial services: the development of Islamic money markets, (2008).

20. H. Ahmed, Financial crisis: risks and lessons for Islamic finance, International Journal of Islamic Finance, 1, $\mathrm{N}^{\circ} 1$, 7-32 (2009). 